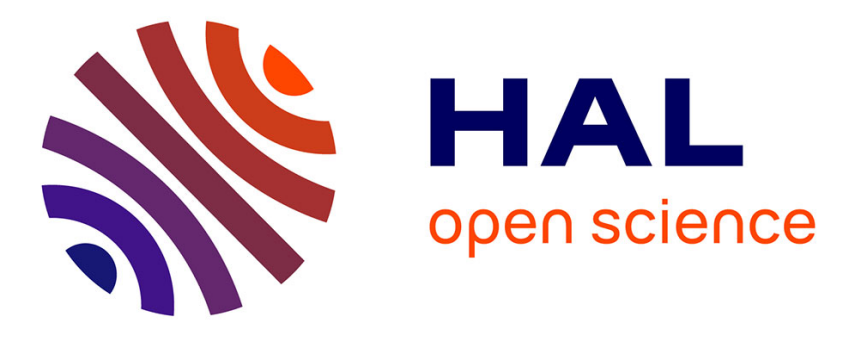

\title{
Punctuated eustatic sea-level rise in the early mid-Holocene
}

Michael Bird, William Austin, Christopher Wurster, Keith Fifield, Meryem Mojtahid, Chris Sargeant

\section{- To cite this version:}

Michael Bird, William Austin, Christopher Wurster, Keith Fifield, Meryem Mojtahid, et al.. Punctuated eustatic sea-level rise in the early mid-Holocene. Geology, 2010, 38 (9), pp.803 - 806. 10.1130/G31066.1 . hal-03277997

\section{HAL Id: hal-03277997 \\ https://univ-angers.hal.science/hal-03277997}

Submitted on 5 Jul 2021

HAL is a multi-disciplinary open access archive for the deposit and dissemination of scientific research documents, whether they are published or not. The documents may come from teaching and research institutions in France or abroad, or from public or private research centers.
L'archive ouverte pluridisciplinaire HAL, est destinée au dépôt et à la diffusion de documents scientifiques de niveau recherche, publiés ou non, émanant des établissements d'enseignement et de recherche français ou étrangers, des laboratoires publics ou privés. 


\title{
Punctuated eustatic sea-level rise in the early mid-Holocene
}

\author{
Michael I. Bird ${ }^{1, *}$, William E.N. Austin², Christopher M. Wurster ${ }^{1}$, L. Keith Fifield ${ }^{3}$, Meryem Mojtahid ${ }^{4}$, and Chris Sargeant ${ }^{2}$ \\ 'Earth and Environmental Science, James Cook University, PO Box 6811, Cairns, Queensland 4870, Australia \\ ${ }^{2}$ Geography and Geosciences, University of St Andrews, Fife KY16 9AL, Scotland, UK \\ ${ }^{3}$ Research School of Physics and Engineering, Australian National University, Canberra, ACT 0200, Australia \\ ${ }^{4}$ National Oceanography Centre, University of Southampton, Southampton S014 3ZH, UK
}

\begin{abstract}
Whether eustatic sea-level rise through the Holocene has been punctuated or continuous has remained controversial for almost two decades. Resolving this debate has implications for predicting future responses of remaining ice sheets to climate change and also for understanding the drivers of human settlement and dispersal patterns through prehistory. Here we present a sea-level curve for the past $8900 \mathrm{yr}$ from Singapore, a tectonically stable location remote from iceloading effects. We also present critical and unique sedimentation rate, organic $\delta^{13} \mathrm{C}$, and foraminiferal $\delta^{13} \mathrm{C}$ proxy records of sea-level change derived from a shallow-marine sediment core from the same area over the same time interval. The sea-level curve, corroborated by the independent proxy records, suggests rapid rise at a rate of $1.8 \mathrm{~m} / 100 \mathrm{yr}$ until 8100 cal (calibrated) yr B.P., a near cessation in the rate of sealevel rise between 7800 and 7400 cal yr B.P., followed by a renewed rise of 4-5 m that was complete by 6500 cal yr B.P. We suggest that this period of relatively stable sea level during the early to mid-Holocene enabled modern deltas to advance, providing a highly productive environment for the establishment of coastal sedentary agriculture. Periods of rapid sea-level rise before and after may have catalyzed significant postglacial episodes of human dispersal in coastal regions.
\end{abstract}

\section{INTRODUCTION}

Fairbanks (1989) first suggested that the rate of meltwater supply to the global ocean during deglaciation was not constant, and Blanchon and Shaw (1995) concluded from coral dating in the Bahamas that a "catastrophic rise event" (also called CRE-3, Melt Water Pulse 3, MWP-1d) raised sea level by $5-6 \mathrm{~m}$ over a few hundred years immediately following $7600 \mathrm{cal}$ yr B.P. (calibrated radiocarbon years before 1950) Since that time considerable additional research effort based on a wide range of coral, sedimentary, and geophysical records around the world have suggested, but not proved, the existence of stepped sea-level rise at intervals in the early Holocene, and the magnitude and timings of periods of slow versus fast sea-level rise vary widely between individual studies (Blanchon and Shaw, 1995; Blanchon et al., 2002; Liu et al., 2004; Yu et al., 2007; Bird et al., 2007; Tamura et al., 2009; Bard et al., 2010). Other studies have concluded that eustatic sea level rose smoothly through the early Holocene (Bard et al., 1996; Toscano and Macintyre, 2003).

Unambiguously resolving inflections within any sea-level record is difficult. This is due to the ambiguities associated with determining the relationship between a dated sample and paleo-sea level, the large isostatic and/or tectonic corrections that are required at some sites, and large, often site-specific uncertainties in dating that vary with both environment and dating technique (Edwards, 2006; Stanley, 2001; Woodroffe and Horton, 2005). These uncertainties are compounded when several records from dispersed locations are overlain for comparison.

Bird et al. (2007) presented a high-resolution sea-level record from $6500-8500$ cal yr B.P. from $-16 \mathrm{~m}$ to $+2.5 \mathrm{~m}$ relative to modern mean sea level (Fig. 1), and suggested, but could not conclusively demonstrate, that eustatic sea-level rise slowed or ceased for a period of a few hundred years following $7900 \mathrm{cal}$ yr B.P., rising rapidly by $2-4 \mathrm{~m}$ shortly after 7500 cal yr B.P. This study seeks to further test the inference of the earlier study by refining and extending the sea-level curve of Bird et al. (2007) and

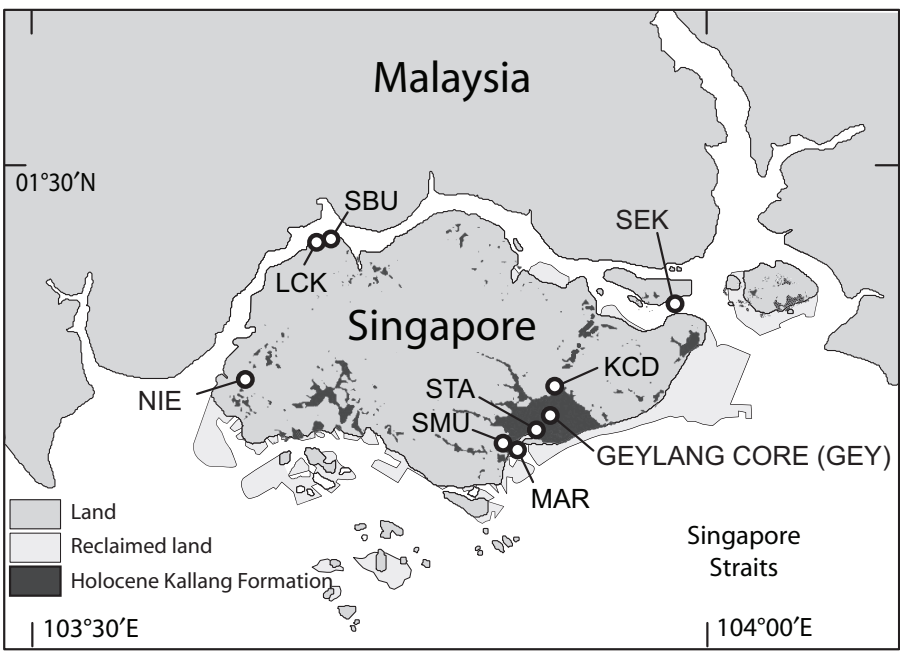

Figure 1. Location of Geylang core and other cores and areas.

developing multiple proxies for sea level using a shallow-marine sediment core from the same area.

\section{STUDY AREA AND METHODS}

A $30 \mathrm{~m}$ sediment core was obtained from downtown Singapore (Geylang district; $1.313713^{\circ} \mathrm{N} ; 103.891772^{\circ} \mathrm{E},+2.65 \mathrm{~m}$ relative to modern mean sea level, rsl; Fig. 1). The $16 \mathrm{~m}$ core records the Holocene marine transgression from $8900 \mathrm{cal}$ yr B.P. in a uniform sequence of fine gray marine clays, overlain by $\sim 1.5 \mathrm{~m}$ of transgressive mangrove peat that prograded over the site in the past $1500 \mathrm{yr}$ as sea level dropped from its regional mid-Holocene high of $+2.5 \mathrm{~m}$.

Key to interpreting the record in the core in terms of sea level is the location of the core in a low-energy, mangrove-fringed Holocene embayment, remote from any significant fluvial source of sediment. The Holocene Upper Marine Clay accumulated at the site is largely derived erosion of the Lower Marine Clay, deposited during the last interglacial period of high sea level along with sediment eroded from the unlithified, deeply weathered, kaolinite-rich Old Alluvium of Tertiary age. Both these units underlie much of the modern Straits of Singapore (Bird et al., 2006).

The upper $1 \mathrm{~m}$ of undisturbed sediment ( -0.35 to $-1.35 \mathrm{~m}$ rsl) consists of sandy peat with abundant large organic fragments, and occasional clean sand beds as much as $5 \mathrm{~cm}$ thick. The mangrove overlies a 13.65-m-thick sequence of Upper Marine Clay ( -1.35 to $-15.0 \mathrm{~m} \mathrm{rsl}$ ), a homogeneous sequence of clays ranging from greenish-gray (10GY 4/1) to gray (5G 5/1), with diffuse laminations $1-2 \mathrm{~mm}$ thick throughout. Both dry bulk density $\left(0.89 \pm 0.07 \mathrm{~g} / \mathrm{cm}^{3} ; \mathrm{n}=105\right)$ and organic carbon content $(0.94 \pm 0.18 \% \mathrm{C}, \mathrm{n}=105)$ of the sediments are very consistent throughout (Table DR1 in the GSA Data Repository').

${ }^{1}$ GSA Data Repository item 2010226, Tables DR1-DR3, is available online at www.geosociety.org/pubs/ft2010.htm, or on request from editing@geosociety .org or Documents Secretary, GSA, P.O. Box 9140, Boulder, CO 80301, USA. 
The stable isotope composition of organic carbon and carbonate is widely used as a proxy in paleoenvironmental reconstruction and can be used to quantify the relative proportions of marine versus terrestrially derived water and carbon in a range of sample materials (Bouillon et al., 2008), thus providing information on coastline proximity and hence sea level. Details for the methodologies used for foram and organic carbon isotope analysis are provided in Tables DR1 and DR2.

The radiocarbon chronology for the Geylang core was constructed by dating 13 cleaned, single bivalves or gastropods, and 2 samples of macroscopic mangrove wood (Fig. 2A; Table DR3). The modern elevation of these samples was measured to $\pm 5 \mathrm{~cm}$, with allowance for as much as $0.5 \mathrm{~m}$ of lowering due to autocompaction (Bird et al., 2007). Of the 50 samples used by Bird et al. (2007) in construction of the sea-level curve, 15 were redated for this study at higher precision (Table DR3). In addition, the total number of index points available for the sea-level curve has been augmented by 10 dates from $6500 \mathrm{cal}$ yr B.P. to the present (Table DR3). Discussion of the Singapore sea-level curve and an analysis of the uncertainties associated with the curve were provided in Bird et al. (2007). Details of calibration to calendar years and determination of local reservoir effects are provided in Table DR3.

\section{RESULTS AND DISCUSSION}

The extended sea-level curve for Singapore (Fig. 2A) provides a record for Holocene sea level in Singapore that is consistent with an inflection in the rate of sea-level rise between 7800 and $7400 \mathrm{cal}$ yr B.P. However, dispersion in the data due to uncertainties associated with elevation, potential minor reworking, and analytical error means that this interpretation cannot be considered conclusive, as previously concluded by Bird et al. (2007).

The Geylang core provides both physical and geochemical proxy records that can be used to provide additional independent constraints on eustatic sea-level rise. As the sea flooded the Straits of Singapore, and with limited opportunity for stabilization by mangrove progradation during rapid marine transgression, sediment accumulated rapidly at the core site. The chronology for the core (Fig. 2A) suggests rapid sediment accumulation, at as much as $1 \mathrm{~cm} / \mathrm{yr}$, between 8500 and $7800 \mathrm{cal}$ yr B.P., coincident with a rapid rise in sea level of $1.8 \mathrm{~cm} / \mathrm{yr}$. Between 7800 and $7400 \mathrm{cal} \mathrm{yr}$ B.P., coincident with the near cessation inferred from the sea-level curve, the rate of sediment accumulation at the core site decreased by an order of magnitude to $\sim 0.1 \mathrm{~cm} / \mathrm{yr}$, at a water depth of $\sim 4 \mathrm{~m}$ (Fig. 2C). After 7400 cal yr B.P., the rate of sediment accumulation increased progressively to $\sim 0.5 \mathrm{~cm} / \mathrm{yr}$, before dropping by an order of magnitude to an average of $0.05 \mathrm{~cm} / \mathrm{yr}$ upon attainment of the mid-Holocene highstand after 6500 cal yr B.P. The rapid drop in sedimentation rate between 7400 and 7800 cal yr B.P. is consistent with the hypothesis that provision of abundant sediment accompanying rapid sea-level rise ceased as the result of stabilization of sea level at that time, as was the case when sea level stabilized again during the mid-Holocene highstand after $6500 \mathrm{cal}$ yr B.P.

Water depth at the core site during the Holocene was controlled by both the rate of sea-level rise and the rate of sediment accumulation. Subtraction of the depth to sediment-water interface in the Geylang core (Fig. 2A) from the inferred maximum and minimum sea-level envelope derived from the sea-level curve (Fig. 2A) provides a broad estimate of water depth (Fig. 2B). This suggests that water deepened rapidly at the core site to a maximum of $\sim 6 \mathrm{~m}$ shortly before $8000 \mathrm{cal}$ yr B.P. Water depth then decreased to $\sim 4 \mathrm{~m}$ between 7800 and $7400 \mathrm{cal}$ yr B.P. After ca. 6000 cal yr B.P., water depth decreased slowly, ultimately leading to mangrove progradation over the site. While the errors on the estimate of water depth are comparatively large, it is clear that the location remained fully subtidal until the late Holocene.

The carbon isotope composition $\left(\delta^{13} \mathrm{C}\right)$ of organic matter in the core reflects the relative input from terrestrial, dominantly mangrove-derived,

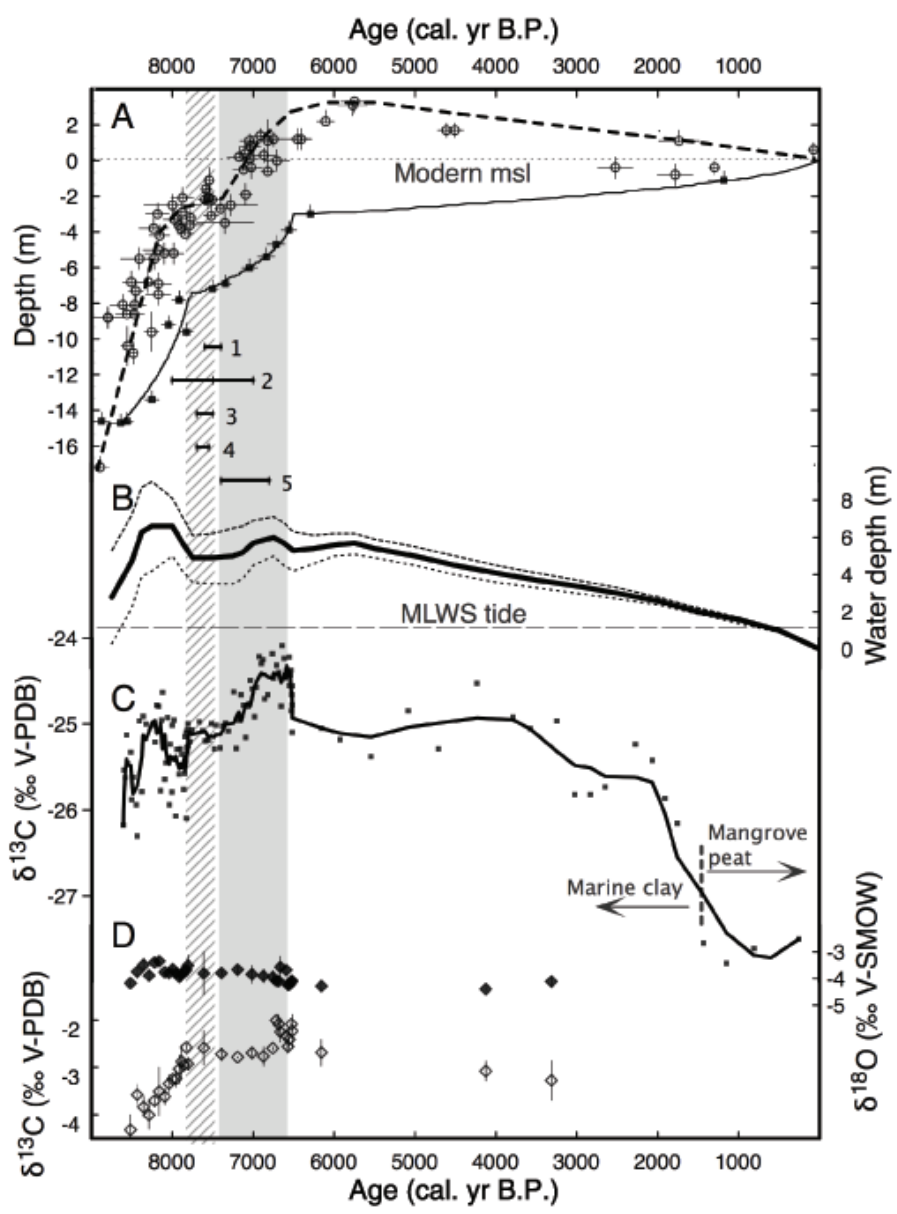

Figure 2. Sea-level curve for Singapore and results from Geylang core. A: Open circles-relative sea-level curve from 8800 cal (calibrated) yr B.P. to present based on new radiocarbon dates of sealevel index points (Table DR3; see footnote 1) and data of Bird et al. (2007) (msl-mean sea level). Generalized trend through data shown by dashed line is within $2 \sigma$ error of $88 \%$ of dates (excluding three results between 1000 and $3000 \mathrm{cal}$ yr B.P., all of which represent samples underlain by thick mangrove peat subject to significant autocompaction). Filled squares-radiocarbon dated samples from Geylang core. Age-depth model (solid line) was calculated using three quadratic functions representing periods of differing sedimentation rate corresponding to before $7800,7800-6500$ and after $6500 \mathrm{cal}$ yr B.P. Key intervals of near cessation of sea-level rise before $7400 \mathrm{cal}$ yr B.P. and renewed rise after $7400 \mathrm{cal}$ yr B.P. are shown by shaded areas. Other studies are indicated by horizontal lines: 1-Rapid sea-level rise, Caribbean (Blanchon and Shaw, 1995; Blanchon et al., 2002). 2-Stillstand followed by rapid flooding of the Mekong delta (Tamura et al., 2009). 3-Rapid sea-level rise, Baltic Sea (Yu et al., 2007). 4-Yangtze delta rice cultivation (Zong et al., 2007). 5-Rapid melting of Labrador sector of Laurentide ice sheet (Carlson et al., 2007, 2008). B: Water depth at Geylang core site is shown by solid line, dotted lines represent lower and upper limits. Mean low-water spring tide depth (MLWS, $-1.2 \mathrm{~m}$ ). C: $\delta^{13} \mathrm{C}$ values of organic carbon in the Geylang core (solid squares), with three-point running mean (solid line). V-PDB-Vienna Peedee belemnite. D: $\delta^{13} \mathrm{C}$ (open diamonds) and $\delta^{18} \mathrm{O}$ (solid diamonds) of benthic foraminifera. Both Ammonia spp. and Elphidium spp. were analyzed in each sample. The $\delta^{13} \mathrm{C}$ of Elphidium spp. was on average $0.48 \%$ 。 lower than Ammonia spp. sample from same interval, due to differing vital effects. Hence this amount was added to Elphidium $\delta^{13} \mathrm{C}$ results before calculation of an average ammonia spp equivalent $\delta^{13} \mathrm{C}$ value, with quoted error being deviation from mean. There was no significant difference between $\delta^{18} \mathrm{O}$ values of these two species, so results were averaged, with quoted error being deviation from mean. V-SMOWVienna standard mean ocean water. 
carbon $(\sim-27 \%$ ) and marine-derived carbon ( $-21 \%$ ) , in turn a measure of coastline proximity (Bouillon et al., 2008) and hence a measure of sealevel change. Figure $2 \mathrm{C}$ shows that organic $\delta^{13} \mathrm{C}$ values track the inferred water depth at the site (Fig. 2B), rising from relatively more negative (dominantly terrestrial) values to a high of $\sim-25 \%$ o shortly before 8000 cal yr B.P. and rapidly dropping thereafter to $7900 \mathrm{cal}$ yr B.P. This trend reflects initial rapid deepening followed by shallowing and rapid mangrove progradation, made possible by the maintenance of high rates of sediment supply until the rate of sea-level rise slowed after the $8.2 \mathrm{ka}$ event (Kendall et al., 2008). $\delta^{13} \mathrm{C}$ values stabilized between 7800 and $7400 \mathrm{cal}$ yr B.P. as sea level stabilized, but then rose to a second maximum of $\sim-24 \%$ o shortly before $6500 \mathrm{cal}$ yr B.P. A rapid drop in $\delta^{13} \mathrm{C}$ values at the onset of Holocene highstand conditions suggests that mangroves were again able to advance as the rate of sea-level rise slowed toward the mid-Holocene highstand. After $6500 \mathrm{cal}$ yr B.P., $\delta^{13} \mathrm{C}$ values stabilized and ultimately decreased to terrestrial $\delta^{13} \mathrm{C}$ values as mangroves became established on the site.

The averaged $\delta^{13} \mathrm{C}$ and $\delta^{18} \mathrm{O}$ values of two species of benthic foraminifera (Ammonia spp. and Elphidium spp.) are shown in Figure 2D. $\delta^{13} \mathrm{C}$ increased rapidly from $-4.5 \%$ o to $-2.8 \%$ o until 7800 cal yr B.P. during the early period of rapid sea-level rise. Thereafter $\delta^{13} \mathrm{C}$ values stabilized at $-2.8 \%$ o until $6900 \mathrm{cal}$ yr B.P., when $\delta^{13} \mathrm{C}$ values rapidly increased to $-1.9 \%$ o before decreasing at $6500 \mathrm{cal}$ yr B.P. The $\delta^{13} \mathrm{C}$ of these species is influenced by proximity to terrestrially sourced dissolved inorganic carbon (DIC) from adjacent mangrove areas (Bouillon et al., 2008). Hence the initial rise in $\delta^{13} \mathrm{C}$ values of these foraminifera is consistent with the inferred rapid increase in water depth at the time, and subsequent stabilization in $\delta^{13} \mathrm{C}$ values is also consistent with a near cessation in sea-level rise. It is important to note that, for these benthic species, $\delta^{13} \mathrm{C}$ values will also be partly determined by $\delta^{13} \mathrm{C}$ values of DIC remineralized from respired organic matter from the underlying sediment. As the thickness of the sediments increased, remineralization-derived DIC would have increased, partly masking any rapid $\delta^{13} \mathrm{C}$ response due to sea-level change. Thus while the cessation of sea-level rise is clearly marked at $7800 \mathrm{cal}$ yr B.P., the response of foraminferal $\delta^{13} \mathrm{C}$ values to renewed sea-level rise after $7400 \mathrm{cal}$ yr B.P. is delayed and muted relative to the organic $\delta^{13} \mathrm{C}$ response.

After ca. $6500 \mathrm{cal}$ yr B.P. $\delta^{13} \mathrm{C}$ again decreased in response to sealevel fall and mangrove progradation, further supporting the link between foram $\delta^{13} \mathrm{C}$ values and coastline proximity. The $\delta^{18} \mathrm{O}$ values of the forams (Fig. 2D) show little systematic variability and no anomalies associated with the changes in sea level implied by the other proxy records, providing further evidence that the variations in sedimentation rate and carbon isotope composition observed in the core were not driven by large local perturbations in circulation or climate.

Other studies have suggested the possibility of a rapid rise in sea level ca. 7500 cal yr B.P. (Blanchon and Shaw, 1995; Blanchon et al., 2002; Liu et al., 2004; Yu et al., 2007; Bird et al., 2007; Tamura et al., 2009), but none have catalyzed general acceptance of the existence of such an event. This study links a high-resolution sea-level record with three independent proxy records of sea level (sedimentation rate and organic and foram $\delta^{13} \mathrm{C}$ values) derived from a shallow-marine core in the same tectonically and climatically stable continental location, remote from isostatic ice-loading effects. A fourth proxy, foraminiferal $\delta^{18} \mathrm{O}$, allows us to eliminate major changes in climate or circulation as a confounding effect. Synthesis of these independent records suggests that sea level rose rapidly until shortly after the 8.2 ka event, slowing sufficiently after that time to allow mangrove progradation and slowing dramatically or stopping between 7800 cal yr B.P. and $7400 \mathrm{cal}$ yr B.P. After $7400 \mathrm{cal}$ yr B.P. sea level again rose by $\sim 4 \mathrm{~m}$ by 6500 cal yr B.P., accompanied by further mangrove progradation. A mid-Holocene highstand of $\sim+2.5 \mathrm{~m}$ was reached after $6500 \mathrm{cal} \mathrm{yr}$ B.P., followed by a lowering, with mangroves prograding over the core site by ca. $1000 \mathrm{cal}$ yr B.P.
Melting of the Northern Hemisphere ice sheets and Antarctica, including the catastrophic draining of Lake Agaziz-Ojibway, is thought to have provided the meltwater flux that drove sea-level rise until ca. 8000 cal yr B.P. (e.g., Kendall et al., 2008). Recent work has also indicated that after a period of relative stability between 8.0 and $7.4 \mathrm{ka}$ (based on ${ }^{10} \mathrm{Be}$ exposure dating), the Labrador sector of the Laurentide ice sheet melted rapidly between 7.4 and $6.8 \mathrm{ka}$, contributing $\sim 3 \mathrm{~m}$ of equivalent sea level (Carlson et al., 2008). Both the timing and magnitude of this melting event are consistent with the conclusions of this study, although meltwater contributions from Antarctica after $7400 \mathrm{cal}$ yr B.P. and into the later Holocene are also possible (Conway et al., 1999; Stone et al., 2003).

Horton et al. (2005) modeled sea level at two locations close to Singapore. Their results suggest rates of sea-level rise of 0.4 to $0.5 \mathrm{~cm} / \mathrm{yr}$, with sea level modeled to be 5-9 m below modern mean sea level at 9000 cal yr B.P., rising to +1 to $+3 \mathrm{~m}$ above modern mean sea level at 7000 cal yr B.P., with a highstand of +2 to $+4 \mathrm{~m}$ at $6000 \mathrm{cal}$ yr B.P. at each location. The 1000 yr time step used by Horton et al. (2005) does not enable direct comparison with the centennial-scale variations in the rate of sealevel rise reported here. However, the results reported here suggest that sea level rose by $1.8 \mathrm{~cm} / \mathrm{yr}$ from $8800 \mathrm{cal}$ yr B.P. to $8100 \mathrm{cal} \mathrm{yr} \mathrm{B.P.} \mathrm{(Fig.} \mathrm{2A),}$ a rate that is significantly higher than suggested by Horton et al. (2005). This is partly attributable to additional meltwater input associated with the 8.2 ka event (Kendall et al., 2008), but might also provide support for the suggestion that sea-level rise in the Holocene prior to 8100 cal yr B.P. was also stepped (Liu et al., 2004).

At other locations similar to Singapore, remote from ice-loading effects, including the major delta areas of Southeast Asia, a period of relative sea-level stability would have provided a distinct interval for delta initiation and progradation. Stanley and Warne (1994) found a modal peak in global delta initiation between 7800 and 8200 cal yr B.P., at which time one-third of major deltas were initiated. In Southeast Asia, for example, in the $400 \mathrm{yr}$ between 7800 and $7400 \mathrm{cal}$ yr B.P., as much as $1400 \mathrm{Gt}$ of sediment would have been delivered to the coastal zone, based on modern sediment discharge of major Asian rivers from the Ganges to the Huang He (Milliman and Meade, 1983). This accumulating sediment may have provided a base upon which to build the extensive modern delta complexes that now represent the major food-growing areas of Asia, providing greatly expanded, fertile, resource-rich regions for exploitation by prehistoric human populations by the mid-Holocene.

Early rice cultivation from 7700 cal yr B.P. has recently been demonstrated from the Yangtze delta at Kuahuqiao; the site was abandoned due to renewed sea-level rise ca. $7550 \mathrm{cal}$ yr B.P. (Zong et al., 2007; Innes et al., 2009). Other deltas in the region, including the Mekong and Red Rivers, reached maximum flooding ca. $8000 \mathrm{cal}$ yr B.P., followed by an interval of stability, with some parts of the deltas flooding again after ca. 7500 cal yr B.P. (Tanabe et al., 2006; Tamura et al., 2009). It is possible that this renewed sea-level rise forced dispersal of populations with a previously developed ability to exploit delta resources into new coastal areas.

Human migration in prehistory is thought to have long been associated with coastlines (e.g., Stringer, 2000), and rapid flooding of delta areas after a period of relative stability may have served to focus coastal and/ or maritime human dispersal into a narrow time frame shortly after 7400 cal yr B.P. This possibility is worth further examination in the context of, for example, controversial postulates concerning early Austronesian maritime dispersals before $7000 \mathrm{cal}$ yr B.P. from an eastern Indonesian homeland (Oppenheimer and Richards, 2001).

\section{CONCLUSIONS}

The combination of a high-resolution sea-level curve for Singapore with independently derived indicators of water depth and sea level derived from a shallow-marine sediment core, also from Singapore, suggests that there was a period of no, or minimal, eustatic sea-level rise between 
7800 and 7400 cal yr B.P., separating intervals of more rapid rise before and after. Changes in the rate of eustatic sea-level rise prior to the midHolocene may provide part of an explanation for the initiation of deltas in farfield locations and may have also have served to catalyze and focus episodes of human migration in prehistory.

\section{ACKNOWLEDGMENTS}

This research was funded by the Academic Research Fund of Nanyang Technological University. We thank G. Cook and J. Cali for the provision of some of the data supporting this study.

\section{REFERENCES CITED}

Bard, E., Hamelin, B., Arnold, M., Montaggioni, L.F., Cabioch, G., Faure, G., and Rougerie, F., 1996, Deglacial sea level record from Tahiti corals and the timing of global meltwater discharge: Nature, v. 382, p. 241-244, doi: $10.1038 / 382241 \mathrm{a} 0$.

Bard, E., Hamelin, B., and Delanghe-Sabatier, D., 2010, Deglacial Meltwater Pulse 1B and Younger Dryas sea levels revisited with boreholes at Tahiti: Science, v. 327, p. 1235-1237, doi: 10.1126/science.1180557.

Bird, M.I., Pang, W.C., and Lambeck, K., 2006, The age and origin of the Straits of Singapore: Palaeogeography, Palaeoclimatology, Palaeoecology, v. 241, p. 531-538, doi: 10.1016/j.palaeo.2006.05.003.

Bird, M.I., Fifield, L.K., Chang, C.H., Teh, T.S., and Lambeck, K., 2007, An inflection in the rate of early mid-Holocene sea-level rise: A new sea-level curve for Singapore: Coastal: Estuarine and Shelf Science, v. 71, p. 523 536, doi: 10.1016/j.ecss.2006.07.004.

Blanchon, P., and Shaw, J., 1995, Reef drowning during the last deglaciation: Evidence for catastrophic sea level rise and ice-sheet collapse: Geology, v. 23 , p. 4-8, doi: 10.1130/0091-7613(1995)023<0004:RDDTLD>2.3.CO;2.

Blanchon, P., Jones, B., and Ford, D.C., 2002, Discovery of a submerged relic reef and shoreline off Grand Cayman: Further support for an early Holocene jump in sea level: Sedimentary Geology, v. 147, p. 253-270, doi: 10.1016/ S0037-0738(01)00143-9.

Bouillon, S., Connolly, R., and Lee, S.Y., 2008, Organic matter exchange and cycling in mangrove ecoystems: Recent insights from stable isotope studies: Journal of Sea Research, v. 59, p. 44-58, doi: 10.1016/j.seares.2007.05.001

Carlson, A.E., Clark, P.U., Raisbeck, G.M., and Brook, E.J., 2007, Rapid Holocene deglaciation of the Labrador Sector of the Laurentide Ice Sheet: Journal of Climate, v. 20, p. 5126-5133, doi: 10.1175/JCLI4273.1.

Carlson, A.E., LeGrande, A.N., Oppo, D.W., Came, R.E., Schmidt, G.A., Anslow, F.S., Licciardi, J.M., and Obbink, E.A., 2008, Rapid early Holocene deglaciation of the Laurentide ice sheet: Nature Geoscience, v. 1, p. 620-624, doi: 10.1038/ngeo285.

Conway, H., Hall, B.L., Denton, G.H., Gades, A.M., and Waddington, E.D., 1999, Past and future grounding-line retreat of the West Antarctic: Ice Sheet: Science, v. 286, p. 280-283, doi: 10.1126/science.286.5438.280.

Edwards, R., 2006, Sea levels: Change and variability during warm intervals: Progress in Physical Geography, v. 30, p. 785-796, doi: 10.1177/0309133306071959.

Fairbanks, R.G., 1989, A 17,000 year glacio-eustatic sea level record: Influence of glacial melting rates on the Younger Dryas event and deep ocean circulation: Nature, v. 342, p. 637-642, doi: 10.1038/342637a0.
Horton, B.P., Gibbard, P.L., Milne, G.M., and Stargardt, J.M., 2005, Holocene sea levels and palaeoenvironments of the Malay-Thai Peninsula, Southeast Asia: The Holocene, v. 15, p. 1199-1213, doi: 10.1191/0959683605hl891rp.

Innes, J.B., Zong, Y., Chen, Z., Chen, C., Wang, Z., and Wang, H., 2009, Environmental history, palaeoecology and human activity at the early Neolithic forager/ cultivator site at Kuahuqiao, Hangzhou, eastern China: Quaternary Science Reviews, v. 28, p. 2277-2294, doi: 10.1016/j.quascirev.2009.04.010.

Kendall, R.A., Mitrovica, J.X., Milne, G.A., Törnqvist, T.E., and Li, Y., 2008, The sea-level fingerprint of the 8.2 ka climate event: Geology, v. 36, p. 423-426, doi: $10.1130 / \mathrm{G} 24550 \mathrm{~A} .1$

Liu, J.P., Milliman, J.D., Gao, S., and Peng, C., 2004, Holocene development of the Yellow River's sub-aqueous delta, North Yellow Sea: Marine Geology, v. 209, p. 45-67, doi: 10.1016/j.margeo.2004.06.009.

Milliman, J.D., and Meade, R.H., 1983, World-wild delivery of river sediment to the oceans: Journal of Geology, v. 91, p. 1-21, doi: 10.1086/628741.

Oppenheimer, S.J., and Richards, M., 2001, Slow boat to Melanesia?: Nature, v. 410, p. 166-167, doi: 10.1038/35065520.

Stanley, D.J., 2001, Dating modern deltas: Progress, problems and prognostics: Annual Review of Earth and Planetary Sciences, v. 29, p. 257-294, doi: 10.1146/annurev.earth.29.1.257.

Stanley, D.J., and Warne, A.G., 1994, Worldwide initiation of Holocene marine deltas by deceleration of sea level rise: Science, v. 265, p. 228-231, doi: 10.1126/science.265.5169.228

Stone, J.O., Balco, G., Sugden, D.E., Caffee, M.W., Sass, L.C., III, Cowdery, S.G., and Siddoway, C., 2003, Late Holocene deglaciation of Marie Byrd Land, West Antarctica: Science, v. 299, p. 99-102, doi: 10.1126/science.1077998.

Stringer, C., 2000, Coasting out of Africa: Nature, v. 405, p. 24-27, doi: 10.1038/ 35011166.

Tamura, T., Saito, Y., Sieng, S., Ben, B., Kong, M., Sim, I., Choup, S., and Akiba, F., 2009, Initiation of the Mekong River delta at 8 ka: Evidence from the sedimentary succession in the Cambodian lowland: Quaternary Science Reviews, v. 28, p. 327-344, doi: 10.1016/j.quascirev.2008.10.010.

Tanabe, S., Saito, Y., Vu, Q.L., Hanebuth, T.J.J., and Ngo, Q.L., 2006, Holocene evolution of the Song Hong Red River, delta system, northern Vietnam: Sedimentary Geology, v. 187, p. 29-61, doi: 10.1016/j.sedgeo.2005.12.004.

Toscano, M.A., and Macintyre, I.G., 2003, Corrected western Atlantic sea-level curve for the last 11,000 years based on calibrated ${ }^{14} \mathrm{C}$ dates from Acropora palmata framework and intertidal mangrove peat: Coral Reefs, v. 22, p. 257-270, doi: 10.1007/s00338-003-0315-4.

Woodroffe, S.A., and Horton, B.P., 2005, Holocene sea level changes in the IndoPacific: Journal of Asian Earth Sciences, v. 25, p. 29-43, doi: 10.1016/j .jseaes.2004.01.009.

Yu, S.-Y., Berglund, B.E., Sandgren, P., and Lambeck, K., 2007, Evidence for a rapid sea level rise 7600 yr ago: Geology, v. 35, p. 891-894, doi: 10.1130/G23859A.1.

Zong, Y., Chen, Z., Innes, J.B., Chen, C., Wang, Z., and Wang, H., 2007, Fire and flood management of coastal swamp enabled first rice paddy cultivation in east China: Nature, v. 449, p. 459-462, doi: 10.1038/nature06135.

Manuscript received 27 January 2010

Revised manuscript received 5 April 2010

Manuscript accepted 12 April 2010

Printed in USA

\title{
ERRATUM
}

\section{Increased sediment accumulation rates and climatic forcing in the central Andes during the late Miocene}

\author{
Cornelius E. Uba, Manfred R. Strecker, and Axel K. Schmitt \\ (Geology, Vol. 35, p. 979-982, doi:10.1130/G224025A.1)
}

In the original paper, the authors used six new radiometric ages from two measured stratigraphic sections in southern Bolivia to estimate the sediment accumulation. We showed that climate variability and monsoon intensification during the late Miocene may have been crucial factors in the increased sediment accumulation rates in the central Andes. Unfortunately, errors occurred in the presentation of the data in Figure 2. In the figure, we reported a measured stratigraphic thickness of $1350 \mathrm{~m}$ for the Angosto de Pilcomayo section, instead of the correct $1225 \mathrm{~m}$ thickness. In addition, we mistakenly placed the upper depositional age for the Tariquia Formation of $5.94 \mathrm{Ma}$ (Tang 4) at ca. $1225 \mathrm{~m}$, instead of at the correct 1090 $\mathrm{m}$ stratigraphic level. These errors will ultimately alter the estimated sediment accumulation rates, and thus we have no confidence in our estimation of the sediment accumulation rates. 